\title{
National Study on the Physical Activity Level as a Means of Preserving Health
}

\section{Dan GAIȚ $\breve{1}^{1}$, Mihaela ORAVIȚAN ${ }^{2}$, Claudiu AVRAM ${ }^{3}$}

\begin{abstract}
Among the factors acting as a burden to health, physical inactivity ranks fourth as a risk factor for all-cause mortality and sixth among the risk factor for loss of disability in adjusted life years. Unhealthy diets and physical inactivity are key risk factors for the major noncommunicable diseases such as cardiovascular diseases, cancer and diabetes. It were investigated a sample of 1106 Romanian subjects, aged 18 and over. 53\% of the questioned population is informed regarding the benefits of daily physical activities, but only $35 \%$ of Romanians declare that they find it easy to apply what they know about maintaining health. Their main sources of information are: television (56\%) and Internet (17\%). 49\% perform appropriate physical activity; walking (51\%) and household activities (32\%) are the main physical activities performed by Romanians, while sports are performed by few of those interviewed (running - 12\%, fitness $7 \%$, cycling $-6 \%$, football $-6 \%$, gymnastics $-4 \%$, while all the other did not score over $2 \%$ ). Half of respondents practice physical activities rarely or not at all, and the main reasons for the sedentary behaviour are the lack of time (42\%), lack of money (16\%) or convenience (15\%). Nearly half of Romanians are sedentary. Although the level of information regarding the benefits of physical activities is satisfactory, the degree of putting this information into practice is very small; the population is not sufficiently aware of the necessity to perform physical activities, in spite of the fact that the effects of a sedentary lifestyle are evident.
\end{abstract}

Key words: physical activity, health, Romanians

\section{Acknowledgement}

The present study was financially supported by a research grant offered by Romanian Heart Foundation.

\section{Rezumat}

Printre factorii care sunt o amenințare privind starea de sănătate, inactivitatea fizică este al 4-lea pentru toate cauzele de mortalitate și al șaselea în ceea ce privește durata vieții. Dietele nesănătoase și inactivitatea fizică sunt factori de risc importanți pentru mai multe tiprui de afecțiuni cum ar fi bolile cardiovasculare, cancerul și diabetul. Au fost investigați 1106 subiecți români, cu vârste mai mari de 18 ani. 53\% din populația chestionată s-a declarat informată cu privire la beneficiile activității fizice zilnice, dar doar 35\% dintre români aplică cu ușurință această metodă de menținere a sănătății. Principalele surse de informae sunt: televizorul (56\%), internetul (17\%). 49\% realizează activități fizice corespunzătoare; mersul (51\%) și activitățile gospodărești (32\%) sunt principalele activități fizice realizate de români, în timp ce activitățile sportive sunt practicate de mai puțini dintre aceștia (jogging $-12 \%$, fitness - 7\%, ciclism - 6\%, fotbal $6 \%$, gimnastică $-4 \%$, în timp ce celalalte sporturi acoperă mai puțin de $2 \%$ ). Jumătate din repondenți practică activități fizice foarte rar sau deloc, iar principalele motive invocate sunt lipsa timpului (425), a banilor (16\%) și comoditate (15\%). Apropae jumătate dintre români sunt sedentari. Deși nivelul de informare privind beneficiile activității fizice sunt satisfăcătoare, gradul de punere în practică a acestora este foarte mic; populația nu este suficient de convinsă privind necesitatea de a realiza activități fizice, în ciuda faptului că efectele sitlului de viață sedentar sunt evidente.

Cuvinte cheie: activitate fizică, sănătate, români.

\section{Precizare}

Acest studiu a fost finanțat dintr-un grant oferit de Fundația Română a Inimii.

\footnotetext{
${ }_{1}^{1}$ Professor PhD," Victor Babeș” Medicine and Pharmacy University of Timișoara, Faculty of Medicine, email: dgaita@cardiologie.ro

${ }^{2}$ Associate Professor PhD, West University of Timișoara, Faculty of Physical Education and Sports

${ }^{3}$ Associate Professor PhD, West University of Timișoara, Faculty of Physical Education and Sports
} 


\section{Introduction}

Among the factors influencing the burden to health, physical inactivity ranks fourth as a risk factor for allcause mortality and sixth among the risk factor for loss of disability adjusted life years [1].

Unhealthy diets and physical inactivity are key risk factors for the major non-communicable diseases such as cardiovascular diseases, cancer and diabetes.2,16 Cardiovascular diseases continues to be the main cause of death in Europe accounting for nearly half $(48 \%)$ of all deaths in the region, equivalent to over 4.3 million deaths each year. Just over half of all cardiovascular disease deaths are caused by coronary heart disease and nearly a third are from stroke. These are the main cause of premature deaths too, accounting for $17 \%$ of deaths in men under 65 and $12 \%$ of deaths before the age of 65 in women; stroke accounts for $6 \%$ of death in men and $9 \%$ of women before age of 65 in Europe [1,2]. New analysis conducted by the International Obesity Task Force (IOTF) of the prevalence of overweight and obesity reveals that in Europe, the Americas and Middle East, more than half of all adults are either overweight or obese and in some parts of Europe more than three quarters of older adults are affected, with Eastern Europe having the greatest problems.[2]

Recognizing the opportunity for reducing deaths and diseases worldwide by improving diets and increasing levels of physical activity, the World Health Assembly adopted the WHO Global Strategy on Diet, Physical Activity and Health, in May 2004. This Strategy provides recommend-dations for Member States, WHO, international partners, private sector, civil society and nongovernmental organizations on the promotion of healthy diets and regular physical activity for the prevention of noncommunicable diseases. ${ }^{16}$ Habitual physical activity prevents the development of coronary artery disease (CAD) and reduces symptoms in patients with established cardiovascular disease ${ }^{4}$; there is also evidence that exercise reduces the risk of other chronic diseases, including type 2 diabetes [5], osteoporosis [6], obesity [7], depression[8], cancer of the breast [9] and colon [10,11]. Physical activity has been shown to be important in weight loss, in maintaining it and fulfils all criteria of a causal risk factor of many cardiovascular and metabolic diseases [12]. The risk reduction of various diseases is reflected in the reduced risk of all-cause mortality of $30 \%$ [1].

\section{Methods}

A population-based cross-sectional study was carried out in Romania - an Eastern European Country, with a population of approximately 19,000,000 inhabitants. The target population of this study included all Romanian adults aged 18 to 90 years from rural and urban areas who use telephones and/or mobile phones. We investi-gated a random sample of 1106 Romanian subjects (assuming a theoretical maximum error of $+/-3 \%$ at the $95 \%$ confidence level), stratified according to the size of the settlement and cultural area (stratification of settlements in 8 regions of Romania).

The process of contacting the subjects for the study was performed using the following methodology:

1. For mobile contacts, eligible respondents (aged 18 and over) were interviewed.

2. For fixed contacts, eligible respondents (aged 18 and over) were randomly selected (using the last birthday method) from the household.

A minimum of 3 phone calls have been conduc-ted on different days and at different times, when the subjects could not be contacted on the first call.

The socio-demographic characteristics of the responders are described in Table I.

All 32 interviewers were previously trained for applying health related phone questionnaires. The questionnaire was pre-tested with 40 adults (not included in the sample) and adjusted to be easier to understand by the study subjects. The final version of the questionnaire (14 questions) was applied using CATI (computer-assisted-by phoneinterviewing) method applied between 7th and 15th of February 2012. The interview was performed using the following steps:

- The interviewer sits in front of a computer screen;

- Upon command, the computer dials the telephone number to be called;

- When contact is made, the interviewer reads the questions posed on the computer screen and records the respondent's answers directly into the computer;

- Interim and update reports is compiled instantaneously, as the data are being collected.

The CATI software had built-in logic, which also enhances data accuracy and skip questions that are not applicable or will probe for more detail when warranted. 
Table I. Social and demographic characteristics of the study group

\begin{tabular}{|c|c|c|}
\hline Gender & $\begin{array}{l}\text { male } \\
\text { female }\end{array}$ & $\begin{array}{l}45 \% \\
55 \%\end{array}$ \\
\hline Age & $\begin{array}{l}18-24 \text { years } \\
25-39 \text { years } \\
40-59 \text { years } \\
60 \text { years and over }\end{array}$ & $\begin{array}{l}14 \% \\
29 \% \\
36 \% \\
21 \%\end{array}$ \\
\hline Educational level & $\begin{array}{l}\text { up to } 10 \text { years } \\
\text { secondary education (high school, post-high school) } \\
\text { higher education }\end{array}$ & $\begin{array}{l}38 \% \\
43 \% \\
19 \%\end{array}$ \\
\hline Occupational status & $\begin{array}{l}\text { student } \\
\text { unoccupied (retired households, unemployed) } \\
\text { employee } \\
\text { employer, self-employed }\end{array}$ & $\begin{array}{l}7 \% \\
26 \% \\
42 \% \\
6 \%\end{array}$ \\
\hline Activity sector & $\begin{array}{l}\text { state sector } \\
\text { private sector }\end{array}$ & $\begin{array}{l}23 \% \\
73 \%\end{array}$ \\
\hline Marital status & $\begin{array}{l}\text { unmarried } \\
\text { married, cohabiting } \\
\text { divorced, widowed }\end{array}$ & $\begin{array}{l}20 \% \\
66 \% \\
13 \%\end{array}$ \\
\hline Monthly income* & $\begin{array}{l}\text { below } 1000 \text { lei } \\
\text { between } 1001 \text { and } 2000 \text { lei } \\
\text { between } 2001 \text { and } 3000 \text { lei } \\
\text { between } 3001 \text { and } 4000 \text { lei } \\
\text { over } 4000 \text { lei }\end{array}$ & $\begin{array}{l}31 \% \\
39 \% \\
17 \% \\
6 \% \\
7 \%\end{array}$ \\
\hline Area of residence & $\begin{array}{l}\text { rural poor and medium developed area } \\
\text { rural developed area } \\
\text { small and medium city (under } 100000 \text { citizens) } \\
\text { big city (over } 100000 \text { citizens) }\end{array}$ & $\begin{array}{l}24 \% \\
18 \% \\
26 \% \\
32 \%\end{array}$ \\
\hline
\end{tabular}

The methodology of the study followed the Declaration of Helsinki set of principles and was approved by the Research Review Board of the Victor Babes University of Medicine and Pharmacy from Timisoara.

\section{Results and discussion}

The results of the study, following the application of the questionnaire, have shown that, at a declarative level, approximately half of the population (53\%) is informed regarding the benefits of daily physical activity. Another important segment (32\%) declares that they are partly aware regarding this aspect, while only $15 \%$ of the population declare themselves to be uninformed. We can notice that the characterristics which best define the uninformed persons, can be encountered at the level of education, occupational status and income; the other characteristics do not create significant discrimination between the categories. By analysing the extent to which the population is uninformed at the residential level, we can notice that there are discrepancies between the rural and the urban backgrounds, especially between the large urban and the poor rural or the averagely developed regions (Table II).

\section{Information channels}

The most pervasive channels which inform the general public regarding the benefits of physical activities are: television (78\% of those interviewed have mentioned it, out of which $56 \%$ have said that it is their main source of information) and the Internet (36\% have men-tioned it, $17 \%$ as a main source of information). The other elements of the media (print media, radio) or specialists from the field represent secondary sources of information (Table III).

Implementation of prevention knowledge into daily life

The practical transposition into daily life of the knowledge regarding maintaining an adequate level of health represents an undertaking which segments, in a relatively balanced manner, the investigated population. 
Table II. Results regarding the extent to which the population is uninformed regarding physical activity, transposing knowledge into practice, and sedentariness

\begin{tabular}{|c|c|c|c|c|}
\hline & & $\begin{array}{l}\text { Uninformed } \\
\text { (\%) }\end{array}$ & $\begin{array}{c}\text { Difficult } \\
\text { transposition into } \\
\text { practice (\%) }\end{array}$ & Sedentariness (\%) \\
\hline \multirow[t]{2}{*}{ Gender } & male & 16 & 22 & 8 \\
\hline & Female & 13 & 26 & 14 \\
\hline \multirow[t]{4}{*}{ Age } & 18-24 years & 14 & 16 & 8 \\
\hline & 25-39 years & 13 & 24 & 10 \\
\hline & $40-59$ years & 15 & 30 & 11 \\
\hline & 60 years and over & 20 & 37 & 29 \\
\hline \multirow[t]{3}{*}{ Education level } & up to 10 years & 24 & 40 & 21 \\
\hline & $\begin{array}{l}\text { secondary education (high school, post-high } \\
\text { school) }\end{array}$ & 30 & 45 & 22 \\
\hline & higher education & 7 & 19 & 4 \\
\hline \multirow{3}{*}{$\begin{array}{l}\text { Occupational } \\
\text { status }\end{array}$} & student & 9 & 12 & 6 \\
\hline & $\begin{array}{l}\text { unoccupied (retired households, } \\
\text { unemployed) }\end{array}$ & 11 & 21 & 8 \\
\hline & employee & 19 & 31 & 16 \\
\hline \multirow[t]{5}{*}{ Monthly income } & below 1000 lei & 20 & 36 & 20 \\
\hline & between 1001 and 2000 lei & 14 & 22 & 9 \\
\hline & between 2001 and 3000 lei & 9 & 15 & 7 \\
\hline & between 3001 and 4000 lei & 14 & 18 & 8 \\
\hline & over 4000 lei & 9 & 23 & 6 \\
\hline \multirow{4}{*}{$\begin{array}{l}\text { Area of } \\
\text { residence }\end{array}$} & rural poor and medium developed area & 17 & 26 & 11 \\
\hline & rural developed area & 16 & 30 & 14 \\
\hline & $\begin{array}{l}\text { small and medium city (under } 100000 \\
\text { citizens) }\end{array}$ & 14 & 22 & 11 \\
\hline & big city (over 100000 citizens) & 12 & 21 & 10 \\
\hline
\end{tabular}

Table III. The sources of information on physical activity benefits in study group

\begin{tabular}{lccc}
\hline Sources of information & Source 1 & Source 2 & Source 3 \\
\hline specialists (doctors, teachers, trainers) & 8 & 10 & 6 \\
internet & 17 & 14 & 5 \\
radio & 3 & 11 & 3 \\
tv & 56 & 17 & 5 \\
print media & 6 & 13 & 8 \\
other sources & 7 & 9 & 9 \\
any sources, I don't receive such information & 2 & 24 & 63 \\
\hline
\end{tabular}

* there was specified up to three sources for each repondent, depending on their frequency

Table IV. Physical activity level in study group

\begin{tabular}{lc}
\hline Physical activity level & study group (\%) \\
\hline intense physical activity, at least 20 minutes, 3-4 times/week & 36 \\
intense physical activity, at least 20 minutes, 1-2 times/week & 13 \\
only easy, irregular physical activity & 39 \\
any physical activity & 11 \\
I don't know/ I don't answer & 1 \\
\hline
\end{tabular}


Thus, if 35\% of Romanians declare that they find it easy to apply what they know of health preservation, $41 \%$ of them admit that this under-taking poses a relative number of obstacles, while almost a quarter of Romanians (24\%) declare that it is difficult for them to insert these information into their daily lives. Age, an elementary level of education, associated with an average or low occupational status and with a reduced level of income, all constitute the main obstacles in converting the theoretical knowledge possessed into practice. The discrepancy between the rural and the urban backgrounds when attempting to practically apply the knowledge regarding health preservation has been noticed; this discrepancy can be explained especially by the age differences between the populations of the two residential sectors (a mean age of 49 in the rural area and 43 in the urban area) (Table II).

\section{Declared physical activity}

$57 \%$ of respondents have mentioned that they conduct physical activities on a daily basis, while $43 \%$ have answered negatively regarding this aspect; regarding the frequency and intensity of the physical activity which they conduct, the data indicates that one Romanian out of 9 (11\%) declare that they do not perform any physical activities; 39\% of those from study group declare that they perform only easy, irregular physical activities; in turn, only half of Romanians perform intensive physical activities at least once a week (an intense physical activity of at least 20 minutes, performed 3-4 times/week, was registered for $36 \%$ of respondents; $13 \%$ declared that they perform such activities 1-2 times/week) (Table IV).

A global systematic review of 25 studies in adults, six of which were conducted in Europe, concluded that leisure-time physical activity has been increasing over time for adults, while occupational physical activity has been declining. The presents study results shows that, at least in Romania, the current prevalence of leisure physical activity is still very low.

The fact that conducting physical activities is an undertaking with a significant social dimension is proved by the fact that $60 \%$ of those who conduct these activities do so together with other people. Only $38 \%$ of respondents declare that they perform physical activities alone. Regarding the place where physical activities are performed, the following answers have been recorded: 38\% - at "home", 46\%
- outdoors. Only one person in 11 declares that he/she goes to a gym.

Regarding the type of physical activities, we noticed that the most frequently mentioned physical activities performed by Romanians are "strolling, walking" (51\% mention them), followed by "household activities" (32\%), jogging (12\%) and physical exercises (10\%). The activities mentioned were considerably varied (gardening - $8 \%$, physical activity at work and fitness - $7 \%$, cycling and football - 6\%, aerobics or gymnastics - 4\%, push-ups, crunches or weight lifting - $2 \%$, while tennis, swimming, skiing, dancing or other activities were chosen by $1 \%$ of those inter-viewed).

\section{Sedentary behavior}

A consistent part of the study group is sedentary; according to the data obtained, age and the level of education are the main determiners of sedentary lifestyle. At a residential level, the highest rate of sedentary lifestyle can be observed in the developed rural areas (Table II).

Those who do not perform physical activities $(\mathrm{N}=559)$ have mentioned the following reasons for this: lack of time (42\%) - the most important reason, followed by lack of money (16\%), convenience (15\%); the lack of dedicated facilities constitutes an impediment for performing physical activities only for $2 \%$ of the sedentary respondents.

Comparing with the reality of other European countries we noticed the same profile of physical activity level in Greece. The the main reasons for participation of Greek population in physical activities are health, weight control, fitness and stress management, while lack of time was the main perceived barrier. Influencing factors were age, gender, income, type of work, marital status, residence and educational background [13].

Another study, which investigate the prevalence of and identify factors associated with physical activity among the population of São Paulo, Brazil, shows that the variables associated with insufficient levels of leisure physical activity is low education level, selfreported poor health, older age, female sex, nonwhite skin color and smoking [14].

Both study findings are consistent with our results in which socio-economic conditions have an impact on physical activity levels; the poorer groups have less time, poorer access to leisure facilities and live in environments which are not conductive for physical activity. 
The respondents' state of health, at a declarative level, has been investigated in the last year only in the case of two thirds of the respondents. Elements which can be caused by sedentariness are present under various aspects: $28 \%$ have high blood pressure, $14 \%$ have high values of cholesterol, $6 \%$ have diabetes mellitus or hyperglycaemia, while $51 \%$ present weight osci-llations in the last year. These pieces of informa-tion have been confirmed by other studies which have shown that cardio-metabolic diseases (myocardial infarction, stroke, diabetes mellitus) are the main health problems responsible for the increase in morbidity and mortality in Romania (aspect mentioned in EuroAspire III - the most significant epidemiologic study to prevent cardiovascular diseases in Europe)8; furthermore, the sedentary lifestyle of Romania's population has also been mentioned in the Special Eurobarometer 334 - Sports and physical activity in 2010 [16]. In this document of the European Commission it is mentioned that $69 \%$ of Romanians do not perform regular physical activities.

According to our study, sedentariness is, still, a reality in the lives of many Romanians. Although the level of awareness regarding the benefits of physical activities is satisfactory, the rate of transposition into practice of these knowledge is low; to a significant extent, this is due to lack of time and, to a lesser extent, to convenience and lack of financial resources. Out of the physical activities performed by Romanians, strolling, walking and household activities are preferred, while sports, are performed by few of those interviewed. Effectively, we can say that physical activity is performed in the context of other daily activities (travel to work, household activities) and is not seen as an objective in the daily routine, but only as a means of achieving other objectives.

For these reasons, a wide range of measures should be implemented to encourage cycling, walking and other forms of physical activity as part of people's daily routine. So, it is important that institutional policies focus on increasing physical activity opportunities, ensuring that facilities are available for different groups of the population.

\section{Conclusion}

The results of our study, correlated with the data regarding the high incidence of obesity, of the metabolic syndrome, of cardiovascular and neoplastic diseases in the case of Romania's population, warn us that the population is not sufficiently aware of the necessity of performing physical activities, although the effects of sedentariness are evident. It is absolutely necessary for local and national authorities to adopt more specific, measurable, achievable, realistic and timebounded measures in order to increase the physical activity level of Romanian people.

\section{References}

1. WHO - Gaining Health (2006) The European Strategy for Prevention and Control of Noncommunicalbe Disease, Copenhagen;

2. Eurodiet Project, Eurodiet Core Report (2001) Public Health Nutrition; 4 (2b): 437-8;

3. WHO (2004) Global Strategy on Diet, Physical Activity and Health, WHO, Geneva;

4. European Heart Network (2011) Diet, Physical Activity and Cardiovascular Disease Prevention. November, Brussels;

5. Knowler W.C., Barrett-Connor E., Fowler S.E. et al. (2002) Reduction in the incidence of type 2 diabetes with lifestyle intervention or metformin. N Engl J Med., 346: 393-403.

6. Vuori I.M. (2001) Dose-response of physical activity and low back pain, osteoarthritis, and osteoporosis. Med Sci Sports Exerc.; 33 (6 suppl): S551-S586;

7. Wing R.R., Hill J.O. (2001) Successful weight loss maintenance. Annu Rev Nutr.; 21: 323-341;

8. Pollock K.M. (2001) Exercise in treating depression: broadening the psychotherapist's role. J Clin Psychol.; 57: 1289-1300;

9. Breslow R.A., Ballard-Barbash R., Munoz K. et al.(2001) Longterm recreational physical activity and breast cancer in the National Health and Nutrition Examination Survey I epidemiologic follow-up study. Cancer Epidemiol Biomarkers Prev., 10: 805-8;

10. Lee I.M., Oguma Y. (2002) Physical Activity. In: Shotten-feld D., Fraumeni J.F., editors. Cancer Epidemiology and Prevention. Oxford University Press: 449-68;

11. Slattery M.L., Potter J.D. (2002) Physical activity and colon cancer: confounding or interaction? Med Sci Sports Exerc.; 34: 913-9;

12. US Department of Health and Human Services.(2008) Physical Activity Guidelines Advisory Committee Report, Washington DC;

13. Tzormpatzakis N., Sleap M. (2007) Participation in physical activity and exercise in Greece: a systematic literature review. Int J Public Health.; 52(6):360-71;

14. Florindo A.A., Guimarães V.V., Cesar C.L., Barros M.B., Alves M.C., Goldbaum M. (2009) Epidemiology of leisure, transportation, occupational, and household physical activity: prevalence and associated factors. J Phys Act Health.; 6(5): 625-32;

15. Kotseva K., Wood D., De Backer G., De Bacquer D., Pyörälä K., Keil U. (2009) EUROASPIRE Study Group. EUROASPIRE III: a survey on the lifestyle, risk factors and use of cardioprotective drug therapies in coronary patients from 22 European countries. Eur J Cardiovasc Prev Rehabil. Apr;16(2):121-37;

16. European Commission (2010) Eurobarometer Special Survey 334, Sport and Physical Activity Report. 